\title{
Personal Self-Regulation and Regulatory Teaching to predict Performance and Academic Confidence: new evidence for the DEDEPRO Model ${ }^{\mathrm{TM}}$
}

\section{Jesús de la Fuente ${ }^{1}$, Fernando Justicia ${ }^{2}$ \\ Paul Sander ${ }^{3}$, Maria Cardelle-Elawar ${ }^{4}$,}

\begin{tabular}{c}
\hline${ }^{1}$ University of Almería, Spain \\
${ }^{2}$ University of Granada, Spain \\
${ }^{3}$ Cardiff Metropolitan University, United Kingdom \\
${ }^{4}$ Arizona State University, USA
\end{tabular}

Spain / UK / USA

Correspondence: Jesús de la Fuente Arias. Universidad de Almería. Dpto de Psicología. Carretera Sacramento, s/n. La Cañada de San Urbano. Edificio A de Humanidades, Despacho 2.45. 04120 Almería. SPAIN.

E-mail: jfuente@ual.es

(C) Education \& Psychology I+D+i and Ilustre Colegio Oficial de Psicólogos de Andalucía Oriental (Spain) 


\begin{abstract}
Introduction. The 3P and DEDEPRO Models predict interactive relationships among presage, process, and product variables through teaching and learning of self-regulation. The DEDEPRO Model has established different possibilities for interaction between student characteristics of self-regulation and external characteristics of regulatory teaching. The aim of this investigation is empirical validate the model of four interaction types.

Method. The sample included 765 undergraduate students from two universities in the south of Spain. Using an ex post-facto design, the date collection was obtained from three validated instruments: Self-regulation scale (SRQ), the Scales for Assessment of the Teaching-Learning Process (ATLP-S) and the Academic Behaviour Confidence (ABC) scales at two different points in time. Academic performance was evaluated through the final grade for each subject area. Multivariate Analyses were used and from Structural Equation Modelling was used to explore possible causal relationships.
\end{abstract}

Results. Results offer evidence for a consistent, four-fold interaction typology and empirical causal model, thus giving significant confirmation of the proposed rational model. As predicted, the most significant of these interactions was the student's self-regulation with regulatory instruction.

Conclusion. The best type of interaction is high personal self-regulation with a highly regulated teaching-learning process, yielding high performance and academic confidence.

Keywords: DEDEPRO Model, Personal Self-Regulation, Regulatory teaching, Self-Regulated Learning, Achievement, Academic Confidence.

Received: 08/03/14 Initial acceptance: 09/10/14 Final acceptance: 11/12/14 


\section{Autorregulación personal y enseñanza reguladora para predecir el rendimiento y la confianza académica: nueva evidencia para el modelo DIDEPRO ${ }^{\mathrm{TM}}$}

\section{Resumen}

Introducción. Los modelos 3P y DIDEPRO predicen relaciones interactivas entre variablespresagio-proceso-producto a través de la enseñanza y el aprendizaje autorregulado. El Modelo DIDEPRO ha establecido diferentes posibilidades de interacción entre las de autorregulación del alumno y de la enseñanza reguladora. El objetivo de esta investigación empírica fue validar un modelo racional de cuatro tipos de interacción.

Método. La muestra estuvo formada por 765 estudiantes universitarios de dos universidades del sur de España. Se utilizó un diseño ex post-facto. La recolección de datos se obtuvo a partir de tres instrumentos validados, en dos momentos temporales diferentes: Escala de Autorregulación (SRQ), la Escala para la Evaluación del Proceso de Enseñanza-Aprendizaje (ATLP -S) y la Escala de Comportamiento de Confianza Académica (ABC). El rendimiento académico se evaluó a través de la nota media final de cada materia. Fueron utilizados diferentes análisis multivariantes y un modelo causal empírico que ofrece evidencia de las relaciones postuladas.

Resultados. Ofrecen evidencia de cuatro tipos de interacción constante y modelo causal empírico, dando así una confirmación significativa del modelo racional propuesto. Como se había predicho, la más significativa de estas interacciones fue la autorregulación del estudiante con la instrucción reguladora.

Conclusión. El mejor tipo de interacción es alta autorregulación personal con un proceso de enseñanza-aprendizaje altamente regulador, produciendo un alto rendimiento y la confianza académica.

Palabras clave: tipologías DIDEPRO, Autorregulación personal, Enseñanza Reguladora, Aprendizaje autorregulado, Rendimiento, Confianza Académica. 


\section{Introduction}

Worldwide media attention on high-stakes testing has repeatedly challenged educators' proficiency in higher education. Being highly knowledgeable in a subject area does not ensure a successful teaching-learning process. This leads researchers to sharpen their focus on how to meet the requirements of our changing world (Boekaerts \& Corno, 2005; Boekaerts, Koning, \& Vedder, 2006; Chartock, 2010; Gurin, Dey, Hurtado, Gurin, 2009; Light, Cox, \& Calkins, 2009; Minnaert \& Vermunt, 2010; Núñez et al., 2011). For most educators the critical question is how to develop the self-regulated learner while embracing diversity and the complexity of individual differences in learning? Students' self-inquiry, in turn, focuses on how to adapt to different instructional styles and teacher expectations that differ from previous academic experiences.

\section{Personal Self-Regulation}

The role of personal Self-Regulation has been defined as a student variable reference needed. Brown (1998) defines self-regulation as a person's capacity to "plan, monitor and direct their behaviour in changing situations" (p.62). It is the process by which the person generates thoughts, feelings and actions which are then systematically oriented toward achievement of goals (Zimmerman \& Schunk, 2001; Zimmerman, 2002, 2008; de la Fuente et al. in press). Prior studies have demonstrated that self-regulation acts significantly both in health and in academic and work-related success (Karoly, Boekaerts \& Maes, 2005; Vancouver \& Scherbaum, 2008). Self-regulation can be understood as a process with a personal, behavioural and contextual nature (Bandura, 1986). Empirical research has established clear evidence that self-regulation is an important variable of personal competency and autonomy (Fitzsimons \& Finkel, 2011; Song, Kalet \& Plass, 2011). This concept is a general personal quality, unlike self-regulated learning, which refers to specific self-regulation during this process.

\section{Regulatory teaching}

There is a growing body of research claiming to document that regulatory teaching is a strong predictor of self-regulated learning activities (Boekaerts \& Corno, 2005; Boekaerts, Koning, \& Vedder, 2006; De la Fuente, García-Berbén \& Zapata, 2013) but although the teacher's classroom is a powerful context for learning, there is divergent empirical evidence on the interaction between students' learning and the teacher's instructional approach. There 
has also been empirical evidence, to a lesser extent, on the role of different types of teaching in promoting learning, sometimes with contradictory results. Prior investigations have established this relationship (Cleary \& Zimmerman, 2004; Labuhn, Bogeholz \& Hasselhorn, 2008). Lee, Yin and Zhang (2009) also showed the influence of teaching; however, teacherfocused instruction encouraged self-regulated learning among students in Hong Kong. In contrast to these studies, Rotgans and Schmidt (2009) provide evidence for the contextual independence of self-regulated learning. Students who are focused on performance (product) and not on learning (process), do not want a regulatory teaching process nor do they have a selfregulated learning process, as is confirmed in other studies (Bartels, Magun-Jackson \& Kemp, 2009; Pintrich, 2000); instead, they prefer a kind of independent learning.

A context is needed approach to the phenomenon is limited, especially when learning is produced in formal educational contexts, where teaching actions are designed and carried out in order to directly influence and determine how learning is to take place. Thus, studying how the learning process relates to the teaching process has become a central concern in formal instructional situations (Biggs, 2001; Entwistle \& Peterson, 2004; Weinstein \& Mayer, 1986; Vermetten, Vermunt \& Lodewijks 2002). This novel conception, that the processes of teaching and learning (henceforth, TL) are interactive, or have empirically interdependent relationships, has led to the rise of different theoretical models that have received increasing empirical support.

\section{Self-Regulated learning}

Many studies have sought to understand the inherent role played by self-regulated learning as an explanatory, metacognitive-type variable, with broad evidence for the importance of the cognitive and motivational levels of learning (Biggs, 1984; Eisenberg, Spinrad \& Eggum, 2010; Entwistle, 1987; Pintrich, 2004; Torrano \& González, 2004; Zimmerman \& Martínez-Pons, 1988). Research findings showed a relationship between students' learning approaches and the use of self-regulation in the form of better planning and control of execution (Bembenutty, Cleary \& Kisantas, 2013; Case \& Gunstone, 2002; Cleary \& Zimmerman, 2004; Heikkila \& Lonka, 2006; Labuhn, Bogeholz \& Hasselhorn, 2008). The idea of reflective learners having a self-directed strategy refers to two dimensions of thinking: (a) what students as problem solvers know about their own thinking, and (b) their ability and selfconfidence to regulate their own cognitive processes during the act of learning (Bartels, Ma- 
gun-Jackson \& Kemp, 2009; Biggs \& Tang, 2007; Chartock, 2010; Eriksson, 2009; Glasgow \& Hicks, 2009; Kramarski \& Michalsky, 2010; Pintrich, 2004).

\section{Academic confidence}

Self-efficacy - understood as a belief concerning probability of personal success - is a precursor and thus a predictor of academic performance (Bandura, 1997). This is explicit in the extensive work of Bandura and his colleagues and also in research and theorizing specifically located in higher education (Biggs, 1999; Nicholson, Putwain, Connors, \& HornbyAtkinson, 2013). Academic confidence - understood as an anticipated belief in one's adequate performance of the different academic tasks required in a university context- is a more specific term, usually broader focus and as such could be seen as an academic self efficacy construct in contrast to a performance self efficacy construct (de la Fuente, Sander, \& Putwain, 2013; Richardson, Abraham \& Bond, 2012).

\section{Interactive models of the teaching-learning process}

Several educational models have taken into account this interdependent, systematic teaching-learning process. The Weinstein and Mayer Model (Weinstein \& Mayer, 1986) considers that good teaching must include not only content, but should also teach how to learn. The Entwistle Model (1987) centres on evaluation of the most important aspects of the TL process in order to improve instructional performance. Other models have accurately defined the variables that should make up the construct of assessment. The Experiences of Teaching \& Learning Questionnaire (Entwistle \& McCune, 2004; Hounsell, Entwistle \& et al., 20012003) is the assessment instrument for this Model, evaluating subjective experiences of the Teaching and Learning Process. Biggs' 3P Model (2001) focuses on Presage-Process-Product factors of the teaching and learning process. Finally, factors that make up the TL Process have been established either conceptually or empirically through the interactive, instructional DEDEPRO Model, acronym for Design-Development-Product (de la Fuente, 2011; de la Fuente \& Justicia, 2007).

\section{The conception of regulatory teaching for self-regulated learning}

This study is built on the 3P (Biggs, 2001; Entwistle \& McCune, 2004), the DEDEPRO model which summarized, integrated, and interpreted the research findings of the classical models of the presage-process-product paradigms (de la Fuente \& Justicia, 2007). At the 
heart of the DEDEPRO model is the assumption that an interactive relationship between learning and teaching occurs in any instructional situation but especially in formal ones. This assumption implies that students' learning process is influenced by the teaching process and vice-versa.

What is the evidence for types of interactive relationships between the variables within the teaching and learning process? These variables are classified as presage (personal selfregulation), process (regulatory teaching and self-regulated learning) and product (performance and academic confidence in learning). See Figure 1.

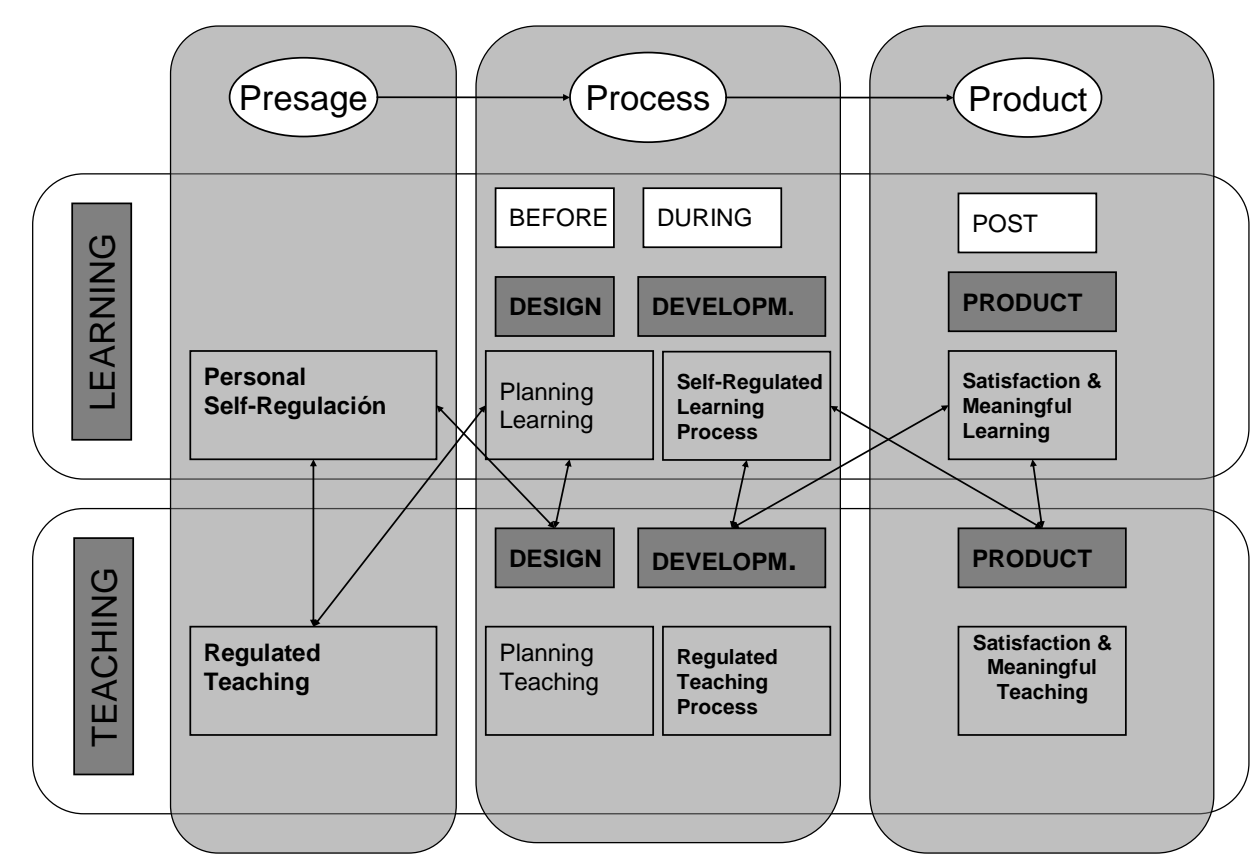

Figure 1.The DEDEPRO Model, inserted in Biggs' 3P Model

1) The presage variable of personal self-regulation refers to the subject's characteristic behaviours of planning, self-control and reassessment in daily situations. Thus, personal selfregulation is a cornerstone of personal development (Bandura, 2005) and should determine the way that students self-regulate the learning process.

2) The process variable of regulation, called regulatory teaching, involves adequate levels of structuring and assistance to facilitate and induce self-regulated learning (Kramarski \& Michalsky, 2009). In complementary fashion, self-regulated learning is the type of learning that involves adequate planning, control and self-assessment (Bembenutty, Cleary \& Kintasas, 2013; Pintrich, 2004; Zimmerman \& Shunck, 2001; Zimmerman, \& Labuhn, 2012), 
and has been associated with achievement (Neuville, Frenay \& Bourgeois, 2007; Pintrich \& De Groot, 1990; Valle, Nuñez, Cabanach, et al., 2008; Vermunt, 2005).

3) The product variable, called satisfaction, performance and academic confidence refers to both the subjective perception of satisfaction and to objective performance, and has been amply documented in the Biggs model (2001). Academic confidence, as a product, refers to understanding how confident students are in their expectations of teaching, learning and assessment of both processes (Sander, 2003, 2004, 2009).

In this interactive conception of the DEDEPRO Model, it is assumed that all the previous variables are found on a low-high continuum, with different types of probabilistic relations, from those that produce the best effects to those that produce the least desirable (see Table 1).

Table 1. Types of relations between levels of variables in the DEDEPRO model, in the context of the 3P model (de la Fuente \& Justicia, 2014)

\begin{tabular}{cccccc}
\hline Type & Presage & \multicolumn{2}{c}{$\begin{array}{c}\text { Process } \\
\text { (Design and Regulated Devel- } \\
\text { opment })\end{array}$} & \\
\hline Level & $\begin{array}{c}\text { Personal Self- } \\
\text { Regulation }\end{array}$ & $\begin{array}{c}\text { Teaching } \\
\text { Regulatory }\end{array}$ & $\begin{array}{c}\text { Learning Self- } \\
\text { Regulated }\end{array}$ & Achievement & $\begin{array}{c}\text { Academic } \\
\text { Confidence }\end{array}$ \\
\hline $4^{\text {o }}$ & High & High & High & High & High \\
$3^{\text {o }}$ & High & Low & Moderate/High & Moderate/High & Moderate/High \\
$2^{\text {o }}$ & Low & High & Moderate/Low & Moderate/Low & Moderate/Low \\
$1^{\text {o }}$ & Low & Low & Low & Low & Low \\
\hline
\end{tabular}

1) Interaction type 4 (high quality level). When the student possesses high personal self-regulation (presage) and is exposed to highly regulatory teaching, he or she will carry out highly self-regulated learning (process), ultimately producing a high level of performance and confidence (product).

2) Interaction type 3 (medium-high quality level). When the student possesses high personal self-regulation (presage) and is exposed to a low level of regulatory teaching, he or 
she will carry out moderately self-regulated learning (process), producing ultimately a moderate-high level of performance and confidence (product).

3) Interaction type 2 (medium-low quality level). When the student possesses low personal self-regulation (presage) and is exposed to highly regulatory teaching, he or she will carry out moderately self-regulated learning (process), producing ultimately a moderate-low level of performance and confidence (product).

4) Interaction type 1 (low quality level). When the student possesses low personal selfregulation (presage) and is exposed to a low level of regulatory teaching, he or she will carry out a low level of self-regulated learning (process), producing ultimately low levels of performance and academic confidence (product).

\section{Aims and hypotheses}

The major objective of this investigation was to validate a rational model of these influences in the quality of student learning by assessing potential interaction types postulated in the rational DEDEPRO model:

1. Determine the four types of interaction relationships between the presage variable (personal self-regulation), the process variables (regulatory teaching and self-regulated learning) and product variables (academic achievement and academic confidence).

2. Establish which variables from the presage dimension (personal self-regulation) and process dimension (regulatory teaching and self-regulated learning) have a predictive relationship with the product dimension (academic achievement and academic confidence), in order to provide empirical evidence for the DEDEPRO model.

Two hypotheses were established based on the DEDEPRO model:

1. Students with high personal self-regulation (presage), in interaction with high/low regulatory teaching (process) will produce high/medium self-regulated learning (process) and high/medium performance and academic confidence (product). This is the case of types 4 and 3. However, students with low personal self-regulation (presage), in interaction with high/low regulatory teaching (process) will produce moderate/low self-regulated learning (process) and medium/low performance and academic confidence (product). This is the case of types 2 and 1. 
2. The interaction types, as determined by (1) the level of personal self-regulation (presage), (2) regulatory teaching (processes), and (3) self-regulated learning (process), will have a positive causal relation with achievement and academic confidence (product).

\section{Method}

\section{Participants}

The 765 subjects for this study were recruited through two universities located in the south of Spain. The mean age of students was 21.95 (4.29); 356 were male and 409 female, of $2^{\circ}$ and $4^{\circ}$ Grade of Psychology.

\section{Instruments}

1. The Personal Self Regulation Questionnaire, SRQ (Brown, Miller \& Lawendowski, 1999), in its Spanish version. The SRQ possesses internal consistency (Alpha of Conbach=.91) and a 2-day stability over time, $r(83)=.94$. Two later studies (Carey, Neal \& Collins, 2004; Neal \& Carey, 2005) focused on a psychometric analysis of the SRQ. The present investigation made use of the original version, which provides more information on the self-regulation sequence we wish to study than does the abbreviated SRQ (Pichardo et al, 2014).

2. The Scales for Assessment of the Teaching-Learning Process, ATLP, student version (de la Fuente et al, 2010) were used to evaluate relationships among design-developmentproduct, from the perspective of students. The ATLP is a self-report instrument to be completed by the teacher and the students, available in Spanish and English versions. It contains a quantitative part with 30 items, 15 that evaluate perception of the teaching process and another 15 that evaluate learning process perception. Responses are on a Likert-type scale, with scores ranging from 1 (totally disagree) to 5 (totally agree). It also includes a qualitative part where students can make recommendations for improving each of the processes evaluated. As for the instrument's external validity, results are also consistent, since there are different interdependent relationships among the perception of variables which exist in an academic environment. Variations in scores for the learning process have proved that the Scale is sensitive to the latter's influence on the teaching-learning process. 
3. Average grade for the specific subject. Students' average grade was obtained from final report cards, as provided by the participating students' teachers, and range from 0 to 10 points for each subject.

4. The Academic Behavioural Confidence Scale (ABC). Sander (2003) suggested that understanding the confidence that students have towards their studies could be important for making sense of students' expectations of teaching, learning and assessment. The Academic Behavioural Confidence ( $\mathrm{ABC}$ ) scale was developed from this idea and tentatively positioned against the established constructs of self-concept and self-efficacy (Sander, 2009; Sander \& Sanders 2006). The scale itself is a psychometric means of assessing the confidence of undergraduate students from Spain and the UK in their own anticipated study behaviours in relation to their degree program, comprised largely of lecture based courses (Sander et al., 2011).

\section{Procedure}

Data was collected within the framework of broader research from a R\&D project. All groups completed the personal self-regulation questionnaire, and during the month of February. At the end of university year (May), the ATLP Scale and the ABC (academic confidence) Scale were administered. Students were urged to respond to the questions with special attention to the specific teaching-learning process of the class subject they were evaluating. Additionally, teachers provided each student's final grade for each subject under evaluation.

\section{Design and data analysis}

An inferential and causal ex post-facto design was used. In the first case, an inferential design serves to establish the relationship between the presage variable (personal self-regulation), the process variables (teaching and learning process), and the product variables (achievement and academic confidence). In the second case, a causal design serves to construct the empirical model from the presage variables (personal self-regulation), the process variables (teaching and learning process), and the product variables (satisfaction with the two processes, achievement and academic confidence).

First, five cluster analyses were carried out in order to determine high-medium-low groups for each variable. Table 2 shows the resulting medians and grouping criteria. 
Table 2. Cluster median for level of each variable

\begin{tabular}{lcccc}
\hline Variable & Low (1) & Medium (2) & High (3) & Point Range \\
\hline Personal Self-Regulation & 186 & 205 & 227 & $63-315$ \\
Regulatory Teaching & 38 & 52 & 62 & $15-75$ \\
Self-Regulated Learning & 42 & 53 & 63 & $15-75$ \\
Academic achievement & 2.60 & 6.34 & 8.09 & $24-120$ \\
Academic confidence & 60 & 71 & & 22 \\
\hline
\end{tabular}

In order to test the proposed hypotheses, two types of statistical analyses were performed, using SPSS 21.0 (Norusis, 2005) and AMOS 21.0 (Arbuckle, 2008) respectively:

1. Univariate (ANOVA) and multivariate (MANOVA) analyses, were used in order to establish the group differences between the presage variable (personal self-regulation), the process variables (teaching and learning process), and the product variables (achievement and academic confidence).

2. Structural equations analysis for constructing the causal empirical model from the presage variables (personal self-regulation), the process variables (teaching and learning process), and the product variables (satisfaction with the two processes, achievement and academic confidence).

\section{Results}

\section{Building an interaction typology}

Type 4 interactions - the most desirable in terms of its effects - are characterized by the interaction of a high level of personal self-regulation (personal development process), with a high level of regulatory teaching (teaching process) and a high level of self-regulated learning (learning process), while type 3 interaction is characterized by the interaction of a high level of personal self-regulation (personal development process), with a low level of regulatory teaching (teaching process) and a moderate level of self-regulated learning (personal development process). Similarly, type 2 interaction is characterized by the interaction of a low level of personal self-regulation (personal development process), with a high level of regulatory 
teaching (teaching process) and a moderate level of self-regulated learning (learning process) and finally, type 1 interaction - the least desirable in terms of its effects - is characterized by the interaction of a low level of personal self-regulation (personal development process) with a low level of regulatory teaching (teaching process) and a low level of self-regulated learning (learning process). This typology is shown in Table 3.

Table 3. Construction of interaction types. Mean score, standard deviation, and percentage

\begin{tabular}{|c|c|c|c|c|c|c|c|c|}
\hline Type & $n=765$ & $\%$ & $P S R$ & $\%$ & $R T P$ & $\%$ & $S R L P$ & $\%$ \\
\hline $4^{\circ}$ & 177 & 23.13 & $.57(.63)$ & 33.10 & $2.87(.34)$ & 44.70 & $2.80(.40)$ & 36.10 \\
\hline $3^{\circ}$ & 147 & 19.21 & $.57(.54)$ & 25.40 & $1.88(.50)$ & 21.95 & $2.56(.61)$ & 23.65 \\
\hline $2^{\circ}$ & 278 & 36.33 & $.38(.53)$ & 25.40 & $2.31(.49)$ & 21.95 & $1.87(.41)$ & 23.65 \\
\hline $1^{\circ}$ & 163 & 21.33 & $.27(.49)$ & 16.10 & $1.19(.48)$ & 11.44 & $1.20(.39)$ & 16.60 \\
\hline
\end{tabular}

PSR: Personal Self-Regulation; RTP: Regulatory Teaching Process; SRLP: Self-Regulated Learning Process

The multivariate analyses (MANOVAs) showed a significant main effect of the interaction typology for the three types of classification variables, $F(9,1083)=63.18, p<.001$ $\left(\mathrm{eta}^{2}=.344\right)$, with the Pillai Trace index. This significant effect also appeared for each of the dependent variables analyzed: personal self-regulation, $F(3,361)=68.63, p<.001\left(\mathrm{eta}^{2}=.361\right)$, regulatory teaching, $F(3,361)=153.63, p<.001 \quad\left(\mathrm{eta}^{2}=.561\right)$ and self-regulated learning, $F(3,361)=100.96, p<.001\left(e^{2}=.456\right)$. In addition, later analyses showed significant differences in personal self-regulation of a high-low type $(4,3>2,1, p<.001)$, regulation of teaching, with high-mid-low types appearing as high, moderate-high, moderate-low and low $(4,3$, $2,1, p<.001)$ and of self-regulated learning, with high-moderate-low $(4>3,2>1, p<.001)$

\section{Typology effects on achievement and academic confidence}

The univariate analysis (ANOVA) showed a significant main effect of interaction type on students' academic performance, $F(3,748)=82.38, p<.001\left(\mathrm{eta}^{2}=.248\right)$. Later analyses showed significant differences of means, $4>3>2>1$ ( $p<.001)$. Similarly, the multivariate analysis (ANOVA) showed a significant main effect for students' academic confidence, $F(3,436)=$ $5.565, p<.001\left(\right.$ eta $\left.^{2}=.037\right)$. Later analyses showed significant differences of means, although 
less powerful, $4>1,(p<.001)$. Table 4 provides the descriptive data that these results are based on.

Table 4. The effects of interaction types on performance and academic confidence

\begin{tabular}{lrrrr}
\hline Type & $n=752$ & Performance & $n=440$ & Confidence \\
\hline 4 & 316 & $2.54(.50)$ & 97 & $2.21(.71)$ \\
3 & 77 & $2.24(.56)$ & 46 & $2.00(.69)$ \\
2 & 283 & $2.03(.36)$ & 222 & $2.00(.72)$ \\
1 & 76 & $1.78(.57)$ & 75 & $1.76(.67)$ \\
\hline
\end{tabular}

Note: Range of Performance and Confidence is: 1 (low) to 3 (high) level

The structural empirical model

The structural equations analysis revealed an initial empirical model showing 6 primary factors and their relationships. The model showed empirical consistency, with reasonable values: Chi-square $=100.28, \mathrm{df}=7, p<.001, R M R=.05$ RMSEA=.051, NFI=.963, RFI=.904, TLI=.911, CFI=.966.

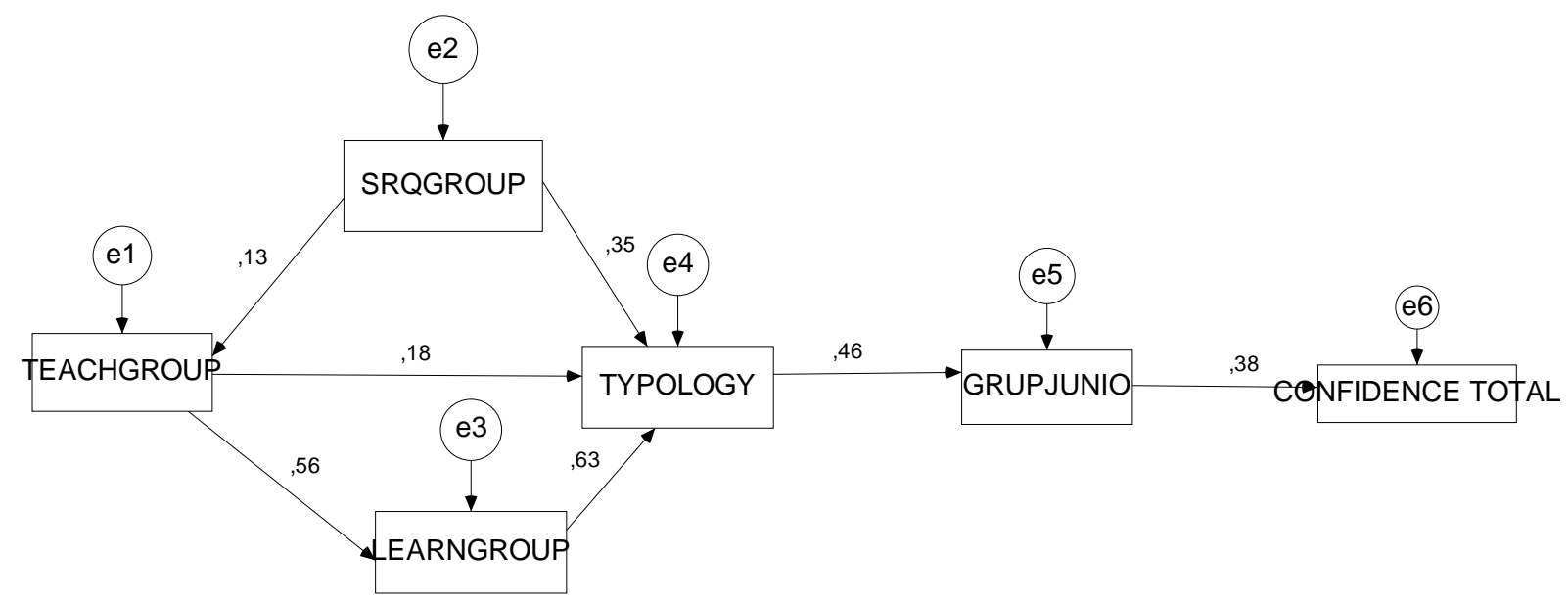

Figure 2. Typology Structural Model of Personal Self-Regulation (presage), Teaching Regulatory and Self-Regulated Learning (process), with respect to Academic Achievement and Academic Confidence (product) 
The variable interaction type is jointly established by personal self-regulation, regulatory teaching and self-regulated learning, and has acceptable, balanced positive indices, although the learning factor bears greater weight. Similarly, a balance is observed among the three variables that make up the type, although greater causal weight lies in the level of selfregulated learning and in the level of personal self-regulation, as compared to regulatory teaching. In addition, interaction type has a positive, quite consistent relationship with performance and with confidence.

\section{Discussion}

Results offer significant empirical evidence in different directions. Regarding the first objective and hypothesis, results support the affirmation that it is possible and useful to empirically categorize the four suggested types of interaction as configurations of a differential combination of personal self-regulation, regulatory teaching and self-regulated learning, as previously defined by rational means. Furthermore, there was confirmation that such an interaction typology has an interdependent effect with university students' performance and academic confidence, being expressed in terms of four levels: (1) the most pernicious, where joining a low level of personal development with teaching that is not helpful for learning does not result in self-regulated learning, but produces the lowest performance and a learning experience that does not induce academic confidence; (2), a level of inadequacy, where low personal development joins with teaching that is helpful for learning, somewhat compensating for the student's deficit, and producing a certain amount of self-regulated learning and an inherently acceptable, if rather low, performance, and externally induced academic confidence; (3) a less-than-optimal level, where a high level of personal development concurs with nonregulatory teaching, leaving process regulation to the students (based on the autonomy required of university students), and which therefore does not make the most of these students' potential for learning. Good if not optimal learning is the result, with adequate but not excellent performance, and an academic confidence effect which is good but less than excellent; (4) the optimal level, where high personal development concurs with regulatory teaching that establishes adequate learning guidelines, thereby making best use of the students' learning potential, producing excellent learning, and necessarily leading to excellent performance and academic confidence. 
These results represent a considerable step forward in explaining the role of individual differences in interaction with different types of teaching-learning processes, and they suggest elements for continued research along these lines (Minnaert \& Vermunt, 2010). Even though there is plentiful evidence for the role of intra-subject variables that determine performance, for example the recent action-emotion style (De la Fuente \& Cardelle-Elawar, 2009), we consider relevant to expand our understanding of different types of interaction that can take place within the instructional context (Rodríguez, Gutiérrez \& Pozo, 2010).

We also recognized that these results demonstrate the importance of understanding the type of students that educators are working with, in terms of their personal self-regulation, given that this variable is essential in the learning processes. A meaningful consideration based on the findings is the need for educators to structure classes to promote students' selfregulatory learning. This recommendation should be implemented independently of students' self-regulatory skills and across the curriculum. In fact, in the case of students with high selfregulation, their performance and academic confidence decline when there is less external regulation, and when students have a lower level of self-regulation, regulatory teaching becomes essential to avoid a drop in performance and self-confidence. In short, these results of the study shed light on the importance of how teachers design instruction that stimulate students become self-regulated learners.

As for the second objective, there is confirmation that interaction types determined by the level of (1) personal self-regulation (presage), (2) regulatory teaching (process), and (3) self-regulated learning (process), has a positive causal relation with achievement and academic confidence (product). This consistent causal relationship shows nuances which must be analyzed and which are coherent with previous evidence. First, there is confirmation that personal self-regulation affects the perception of regulatory teaching, and above all, of selfregulated learning, just as was shown by prior evidence in the classic relationship between performance and learning, as they relate to self-regulation (Vermunt, 1998). Second, we find that the construction of interaction types is defensible, from an empirical standpoint, as it is a combination of three processes which have already been discussed - personal development, teaching and learning. Third, the causal relationship with level of performance and subsequently with the experience of academic confidence is consistent. Therefore, the causal model confirms the multivariate analyses performed previously. 


\section{Implications and limitations}

There are several implications from the results of the investigation. On one hand, they contribute a new construction, called "interaction typology", for analyzing instructional processes of teaching-learning at any educational level, and especially in higher education, where they reinforce Biggs' 3P conception of Presage-Process-Product (Biggs, 2001), as well as the interaction in the Design-Development-Product model, DEDEPRO. On the other hand, the results offer a new interactive methodological strategy for understanding and explaining undergraduate students' performance. Finally, they help verify that there is a diversity of possible interactions among different pupils, with different teaching processes, resulting in different learning processes, levels of performance and academic confidence. This information can be used to evaluate policies in university reforms by taking into account students' levels of satisfaction of their educational performance. Since the teaching process is seen as a decisive contributor to the pupil's learning process, regardless of his or her prior level of personal development. The "journey metaphor" (Pintrich, 2000) is applicable to this situation: in order for students to travel on their own during the learning process, keeping to the proper paths, the latter should be well designed, well constructed and well marked to orient the traveller.

Finally, this research has limitations that must be overcome in future investigations. The single-culture sample does not allow us to generalize results to English-language higher education. However, it does establish a baseline of work from which intercultural research can be carried out, both in higher education and in the school sector.

\section{Conclusion}

In conclusion, if we know the different forms of interaction in the field of Educational Psychology, we must continue to study the combinations between levels of different variables: (1) the student's level or type of personal development process at the start of learning, for different variables, (2) the level or type of formal teaching process that seeks to promote learning and ultimately personal development in a certain domain, and (3) the level or type of formal learning process and contexts, that seeks to contribute to achievement and competency in that domain. This three-dimensioned relationship has been looked on as a powerful research program that can guide research efforts in the 21st century. The new Theory of Self vs. 
Hetero Regulation of Learning (de la Fuente \& Justicia, 2014) can help establish these relationships systematically.

\section{Acknowledgements}

This research was funded through R\&D Project ref. EDU2011-24805 (2012-2014) of the Ministry of Science and Innovation (Spain), and with Federal Funds (European Union). 
Personal Self-Regulation and Regulatory Teaching to predict Performance and Academic Confidence: new evidence for the DEDEPRO Model ${ }^{\mathrm{TM}}$

\section{References}

Arbuckle, J.L. (2008). Amos 16.0. Chicago: SPSS Corporation.

Bandura, A. (1986). Social foundations of thought and action: a social cognitive theory. Englewood Cliffs, NJ: Prentice- Hall.

Bandura, A. (1997). Self-efficacy: The exercise of control. New York: Freeman.

Bandura, A. (2005). Primacy of self-regulation in health promotion transformative mainstream. Applied Psychology: An International Review, 54(2) 245-254.

Bartels, J. M., Magun-Jackson, S., \& Kemp, A. D. (2009). Volitional Regulation and Selfregulated Learning: An Examination of Individual Differences in ApproachAvoidance Achievement Motivation. Electronic Journal of Research in Educational Psychology, 7(2), 605-626.

Bembenutty, H., Cleary, T. y Kisantas, A. (2013). Applications of Self-Regulated Learning across Diverses Disciplines. A tribute to Barry Zimmerman. Charlotte, NC: Information Age Publihing, Inc.

Biggs, J. (1984). Learning strategies, student motivation patterns and subjective perceived success. In R. Kirby (Ed.) Cognitive Strategies and Educational Performance. New York: Academic Press.

Biggs, J. B. (1999). Teaching for quality Learning at University ( $1^{\text {a }}$ ed.). Buckingham: Open University Press.

Biggs, J. (2001). Teaching for Quality Learning at University (2rd ed.). Buckingham: Open University Press.

Biggs, J. \& Tang, C. (2007) Teaching for Quality Learning at University (3rd ed) Buckingham: SRHE and Open University Press.

Boekaerts, M., \& Corno, L. (2005). Self-Regulation in the classroom: A perspective on assessment and intervention. Applied Psychology: An International Review, 54(2), 199231.

Boekaerts, M., De Koning, E., \& Vedder, P. (2006). Goal directed behavior and contextual factors in the classroom: An innovative approach to the study of multiple goals. Educational Psychologist, 41(1), 33-51.

Brown, J. M (1998). Self-regulation and the addictive behaviours. En W.R Miller y N. Heather (Eds.) Treating Addictive Behaviours (pp. 61-73), $2^{\mathrm{a}}$ ed. New York: Prenum Press. 
Brown, J. M., Miller. W. R., \& Lawendowski, L. A. (1999). The Self-Regulation Questionnaire. In L. Vandecreek \& T. L. Jackson (Eds.). Innovations in clinical practice: A source book, Vol. 17 (pp. 281-293). Sarasota. FL: Professional Resources Press.

Boekaerts, M., De Koning, E., \& Vedder, P. (2006). Goal directed behavior and contextual factors in the classroom: An innovative approach to the study of multiple goals, $E d u$ cational Psychologist, 41(1), 33-51.

Carey, K.B., Neal, D.J, \& Collins, S.E. (2004). A psychometric analysis of the self-regulation questionnaire. Addictive Behaviours, 29, 253-260.

Case, J., \& Gunstone, R. (2002). Metacognitive development as a shift in approach to learning: An in-depth study. Studies in Higher Education, 27, 459-470.

Chartock, R. K. (2010). Strategies and Lessons for Culturally Responsive Teaching. New York: Pearson Education

Cleary, T.J., \& Zimmerman, D.J. (2004). Self-regulation empowerment program: A schoolbased program to enhance self-regulated and self-motivated cycles of student learning. Psychology in the Schools, 41(5), 537-550.

Eriksson, I. (2009). Re-interpreting teaching: A divided task in self-regulated teaching practices. Scandinavian Journal of Educational Research, 53(1), 53-70.

de la Fuente, J. (2011). Implications for the DEDEPRO Model for Interactive Analysis of the Teaching-Learning Process in Higher Education. In R. Teixeira (Ed.), Higher Education in a State of Crisis (pp. 205-222). New York: Nova Science Publisher Inc.

de la Fuente, J., \& Cardelle, M.C. (2009). Research on action-emotion style and study habits: Effects of individual differences on learning and academic performance of undergraduate students. Learning and Individual Differences, 567-576.

de la Fuente, J., García-Berbén, A.B., \& Zapata, L. (2013) How regulatory teaching impacts university students' perceptions of the teaching-learning process: The role of teacher training. Infancia y Aprendizaje, 36(3), 375-385.

de la Fuente, J., \& Justicia, F. (2007). The DEDEPRO Model for Regulating Teaching and Learning: recent advances. Electronic Journal of Research in Educational Psychology, 5(3), 535-564.

de la Fuente, J., \& Justicia, F (2014). The new Theory of Self vs. Hetero Regulation of Learning: Foundaments, evaluation, evidence and applicability. Manuscript pending publication.

de la Fuente, J., Sander, P., Justicia, F., Pichardo, M.C., \& Berbén, A.B. (2010). Validation 
Study of the Scale for the Assessment of the Teaching Learning Process, Student version (ATLP-S). Electronic Journal of Research in Educational Psychology, 8(2), 815840.

de la Fuente, J. Sander, P., \& Putwain, D. (2013). Relationship between Undergraduate Student Confidence, Approach to Learning and Academic Performance: The role of gender. Journal of Psychodidactis, 18(2), 373-391.

de la Fuente, J., Zapata, L., Martínez-Vicente, J.M., Sander, P. y Putwain, D. (in press). Personal Self-Regulation, Self-regulated Learning and Coping Strategies, in University Contexts with Stress. In A. Peña-Lara (ed.), Metacognition: Fundaments, Applications and Trends. A Profile of Currents-Stat-of-the-Art (chapter 9). New York: Springer.

Eisenberg, N., Spinrad, T.L., \& Eggum, N.D. (2010). Emotion-related self-regulation and its relation to children's maladjustment. Annual Review of Clinical Psychology, 27(6), 495-525.

Entwistle, N.J. (1987). A model of the teaching-learning process derived from research on students learning. In J. Richardson, M. Eysenk, \& D.W. Arrent-Piper (Eds). Students learning research in educational and cognitive psychology (pp. 13-28). London: Open University Press.

Entwistle, N., \& McCune, V. (2004). The conceptual basis of study strategy inventories. Educational Psychology Review, 16, 325-345.

Entwistle, N.J., \& Peterson, E.R. (2004). Conceptions of learning and knowledge in higher education: relationships with study behavior and influences of learning environments. International Journal of Educational Research, 41(3), 407-428.

Fitzsimons, G.M., \& Finkel, E. J. (2011). Outsourcing self-regulation. Psychology Science, 22 (3), 369-75

Gurin, P., Dey, E.L., Hurtado S., \& Guring, G. (2009). Diversity and Higher Education: Theory and impact on educational outcomes. Harvard Educational Review, 72, 330-367.

Heikkila, A., \& Lonka, K. (2006). Studying in higher education: students' approaches to learning, self-regulation and cognitive strategies. Studies in Higher Education, 31(1), 99-117.

Hounsell, D., Entwistle, N., \& colls. (2001-2003). ETL Project. Enhancing TeachingLearning Environments in Undergraduate Courses. The School of Education, University of Edinburgh. 
Karoly, P., Boekaerts, M., \& Mases, S. (2005). Toward consensus in the psychology of selfregulation: how far have we come? How far do we have yet to travel? Applied Psychology: An International Review, 54(2), 300-311.

Kramarski, B., \& Michalsky, T. (2009). Investigating Preservice Teachers' Professional Growth in Self-Regulated Learning Environments. Journal of Educational Psychology, 101 (1), 161-175.

Labuhn, A.S., Bogeholz, S., \& Hasselhorn, M. (2008). Fostering learning through stimulation of self-regulation in science lessons. Zeitschrift fur Padagogische Psychologie, 22(1), $13-24$.

Lee, J.C.K., Yin, H.B,. \& Zhang, Z.H. (2009). Exploring the Influence of the Classroom Environment on Students' Motivation and Self-regulated Learning in Hong Kong. AsiaPacific Education Researcher, 18(2), 219-232.

Light, G., Cox, R., Calkins, S. (2009). Learning and Teaching in Higher Education: The Reflective Professional (2ed). London: SAGE Publications.

Minnaert, A., \& Vermunt, J.D. (2010). Development of self-regulated learning among freshmen: Toward consonant or beyond dissonant learning patterns? In J. de la Fuente \& M.A. Eissa (Eds.), International Handbook on Applying of Self-Regulated Learning in Different Settings (pp. 279-298). Almería, Spain: Education \& Psychology I+D+i, ePublising Series.

Neal, D.J., \& Carey, K.B. (2005). A follow-up psychometric analysis of the Self-Regulation Questionnaire. Psychology of Addictive Behaviors, 19(4), 414-422.

Nicholson, L.J., Putwain, D.W., Connors, L., \& Hornby-Atkinson, P. (2013). The key to successful achievement as an undergraduate student: confidence and realistic expectations? Studies in Higher Education, 38(2), 272-284. doi: 10.1080/03075079.2011.585710

Neuville, S., Frenay, M., \& Bourgeois, E. (2007). Task value, self-efficacy and goal orientations: Impact on self-regulated learning, choice and performance among university students. Psychologica Bélgica, 47(1-2), 95-117.

Núñez, J. C., Cerezo, R., Bernardo, A., Rosário, P., Valle, A., Fernández, E., \& Suárez, N. (2011). Implementation of training programs in self-regulated learning strategies in Moodle format: results of a experience in higher education. Psicothema, 23(2), 27481. 
Pichardo, M.C., Justicia, F., de la Fuente, J., Martínez-Vicente, J.M. y García-Berbén, A.B. (2014). Factor Structure of the Self-Regulation Questionnaire (SRQ) at Spanish Universities. The Spanish Journal of Psychology, 17, e62, 1-8.

Pintrich, P.R. (2000). Multiple Goals, Multiple Pathways: The Role of Goal Orientation in Learning and Achievement. Journal of Educational Psychology, 92 (3), 544-555.

Pintrich, P.R. (2004). A conceptual framework for assessing motivation and self-regulated learning in college students. Educational Psychology Review, 16 (4), 385-407.

Printich , P.R., \& De Groot, E.V. (1990). Motivational and self-regualted learning components of classroom academic performance. Journal of Educational Psychology, 82, 33-40.

Richardson, M., Abraham, C., \& Bond, R. (2012). Psychological Correlates of University Students' Academic Performance: A Systematic Review and Meta-Analysis. Psychological Bulletin, 138(2), 353-387.

Rodríguez C., Gutiérrez, J., \& Pozo, T. (2010). An empirical study of presage variables on the teaching-learning of statistics in the light of contemporary research on competencies. Electronic Journal of Research in Educational Psychology, 8(1), 235-262.

Rotgans, J., \& Schmidt, H. (2009). Examination of the context-specific nature of selfregulated learning. Educational Studies 35(3), 239-253.

Sander, P. (2009). Measuring Academic Behavioural Confidence: The ABC Scale Revisited. Studies in Higher Education, 7(1), 19-35.

Sander, P., De la Fuente, J., Stevenson, H., \& Jones, T. (2011). A Validation of the Academic Behavioural Confidence Scale with Spanish Psychology Students. Psychology Learning \& Teaching, 10(1), 11-22.

Sander, P., \& Sanders, L. (2006). Understanding Academic Confidence. Psychology Teaching Review, 12 (1), 29-39.

Song, H.S., Kalet, A.L., \& Plass, J.L. (2011). Assessing medical students' self-regulation as aptitude in computer-based learning. Adv Health Sci Educ Theory Pract; 16(1), 97 107.

Torrano, F., \& González, M.C. (2004). Self-regulated Learning: current and futures directions. Electronic Journal of Research in Educational Psychology 2(1), 1-34. 
Valle, A., Núnez, J.C., Cabanach, R.G., Gonzalez-Pienda, J.A., Rodriguez, S., Rosario P., Cerezo, R., \& Munoz-Cadavid, M.A. (2008). Self-regulated profiles and academic achievement. Psicothema, 20(4), 724-731.

Vancouver, J.B., \& Scherbaum C. A. (2008). Do we self-regulated actions or perceptions? A test of two computational models. Computational and Mathematical Organization Theory, 14(1-20).

Vermetten, Y. J., Vermunt, J. D., \& Lodewijks, H. G. (2002). Powerful learning environments? How university students differ in their response to instructional measures. Learning and Instruction, 12, 263-284.

Vermunt, J.D. (1998). The regulation of constructive learning processes. British Journal of Educational Psychology, 68, 149-171.

Vermunt, J.D. (2005). Relations between student learning patterns and personal and contextual factors and academic performance. Higher Education, 49(3), 205-234.

Weinstein, C.D., \& Mayer, R.E. (1986). The teaching of learning strategies. In M. Wittrock, Handbook of Research of Teaching. New York: MacMillan.

Zimmerman, B. J. (2002). Becoming a self-regulated learner: An overview. Theory into Practice, 41(2), 64-70.

Zimmerman, B.J. (2008). Investigating self-regulation and motivation: historical background, methodological developments, and futures prospects. American Educational Research Journal, 45, 166-183.

Zimmerman, B.J., \& Labuhn. A. S. (2012). Self-regulation of Learning: Process Approaches to Personal Development. In K.R. Harris, S. Graham, \& T. Urdam (Eds.), APA Educational Psychology Handbook (vol. 1, pp. 339-425). Washington: American Psychological Association.

Zimmerman, B. J., \& Martínez-Pons, M. (1988). Construct validation of a strategy model of student self-regulated learning. Journal of Educational Psychology, 80, 284-290.

Zimmerman, B.J., \& Schunk, D.H. (Eds.) (2001). Self-regulated learning and academic achievement: Theoretical perspectives ( $2 \mathrm{nd}$ ed.). Mahwah, NJ: Erlbaum. 